VÁRIA 


\title{
Relações oblíquas com a pornochanchada em "P III: duas vezes Ela” de Paulo Emílio Sales Gomes
}

Teodoro Rennó Assunção Universidade Federal de Minas Gerais

\begin{abstract}
“(..) além do charme indiscutível e do gosto pela provocação de um Paulo Emílio ('A senhora assistiu, por acaso, A viúva virgem?', perguntou ele de chofre um dia a Maria Hermínia)" [José Inácio de Melo Souza, em referência às reuniōes do conselho da revista Argumento, que Maria Hermínia Tavares então secretariava]

"Então, um calor monstruoso, não tinha ar refrigerado no hotel. Eram ventiladores. Ele ficava de short, eu ficava de maiô, cada um na sua mesa. E ele dizia: 'Que maravilha, éo próprio calor da inspiração." [Depoimento de Lygia Fagundes Telles sobre estadia em Águas de São Pedro, quando ela estava escrevendo As meninas e Paulo Emílio, Três mulheres de três PPPês]
\end{abstract}

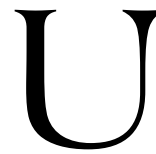

ma crítica mais genérica mas útil reconhece, sem muita dificuldade, como Três mulheres de três PPPês se inscreve, por seu objeto e por sua maneira discursiva, numa certa tradição literária libertina em que ao erotismo se une a sátira (mesmo se os autores que constituem esta tradição variada não cheguem a ser nomeados). Antonio Candido, por exemplo, em breve nota já conhecida e muito citada (de "A nova narrativa"), diz de Paulo Emílio:

A sua livre e extraordinária imaginação sempre aspirou a algo mais, porém só no fim da vida, aos sessenta anos, escreveu os três contos longos do mencionado livro, que tratam de relações amorosas 
complicadas, com uma rara liberdade de escrita e concepção. No entanto, a sua modernidade serena e corrosiva se exprime numa prosa quase clássica, translúcida e irônica, com certa libertinagem de tom que faz pensar em ficcionistas franceses do século XVIII. ${ }^{1}$

Enquanto J. G. Nogueira Moutinho (em "Três mulheres do sabonete Araxá”), também resumidamente, observa (indicando, ao concluir, um aspecto importante de seu estilo paradoxal):

São breves os contos de sua trilogia, mas a cumplicidade de erotismo e de sátira neles existente em alto grau os transforma em elípticas obras-primas. A concisão mesmo favorece a densidade dos relatos, e se o leitor estiver, como diz Georges Bataille, cansado dos limites estreitos impostos pelas convenções, neles descobrirá como é possível violar essas peias sem vulgaridade. ${ }^{2}$

Mais arriscada (porque aparentemente meio descabida) e também até hoje mal explicitada (ou apenas sugerida) é a conexão de Três mulheres de três PPPês (e especialmente de "P III: duas vezes Ela") com a pornochanchada, gênero nascente do cinema brasileiro na época da provável composição do livro (1972-1973), e triunfante quando de sua primeira publicação (1977). Ainda que não a tendo nomeado, é na pornochanchada que quase imediatamente pensamos (mesmo com o necessário recuo devido às óbvias diferenças) ao final desta primeira caracterização do livro de Paulo Emílio por Roberto Schwarz (no com razão já clássico "Sobre as três mulheres de três PPPês"):

Três novelas conjugais, de enredo picante, cheio de surpresas e suspense. Contudo, esta armação é tratada com recuo. Ela serve ao gosto maldoso do autor pelas situações acanastradas, e sobretudo à sua simpatia - esta sem maldade - pelos movimentos vivazes, ainda quando sejam tontos. Aliás, a vivacidade na bobagem parece encerrar para Paulo Emílio alguma coisa preciosa, um atestado de vida e imaginação em regiôes que se julgariam mortas (no campo da crítica de cinema, o seu entusiasmo pelo mau filme nacional talvez tenha a ver com isto)."”

${ }^{1}$ CANDIDO, 1989, p. 215.

${ }^{2}$ MOUTINHO, 2007, p. 120.

${ }^{3}$ SCHWARZ, 2007, p. 125. 
O biógrafo José Inácio de Souza Melo é, no entanto, o único a sugerir explicitamente, em um parêntese breve que apenas enuncia a questão, a conexão do livro de Paulo Emílio com a pornochanchada (ainda que a partir de uma referência algo equivocada a Sade), ao caracterizar sua escrita do seguinte modo:

Sendo ele um leitor infatigável de Eça de Queiroz, um dos roteiristas da adaptação de Dom Casmurro de Machado de Assis para o cinema, (...) grande leitor dos moralistas franceses do XVIII, a escrita ganhou ares de uma fabulação com os pés no realismo, mas também nos aspectos luxuriosos de um Sade (o uso do picaresco era também apropriado aos anos em que se interessou profundamente pelo fenômeno cinematográfico da pornochanchada: havia ou não pornografia naqueles filmes, perguntava-se). ${ }^{4}$ negativa:

Ora, a resposta de Paulo Emílio a esta última questão é sabidamente

Por enquanto não foi feito no Brasil nenhum filme pornográfico. Mesmo vendo os filmes antes de irem à censura, vemos que eles não são pornográficos, inclusive dando à palavra pornografia esta conotação pejorativa, como algo realmente capaz de envenenar a sociedade. (...) Eu nunca vi nesses filmes brasileiros de piores intenções um que tivesse realmente uma atmosfera pestilencial, como vemos freqüentemente em filmes estrangeiros muito bons. ${ }^{5}$

E, continuando uma tentativa de definição (do fenômeno), ele diz:

(...) a grande campanha contra a pornochanchada (...) é feita por gente que não vê os filmes e acredita no que diz a publicidade. Acontece que o próprio nome pornochanchada seria muito mais uma jogada de publicidade do que dos críticos de cinema. O filme Eu dou o que elas gostam, por exemplo, tem esse nome e a publicidade complementar: "E o que elas gostam não é mole", tendo no cartaz o José Lewgoy indicando com a mão as dimensões eventuais do que eles dariam e elas gostariam, tudo indicando muita pornografia. Mas o filme não tem

${ }^{4}$ SOUZA, 2002, p. 558.

${ }^{5}$ Entrevista de Paulo Emílio a Carlos Reichenbach e Inácio Araújo. Cinegrafia 1, julho de 1974, citada por SOUZA, 2002, p. 506. 
absolutamente nada disso - é quase uma comédia de costumes, curiosa, e é só. A pouca relação entre o nome e o filme é incrível. ${ }^{6}$

O problema, portanto, estaria (inversamente ao que à tola crítica moralista visava) justamente no fato de a pornochanchada não mostrar o que anunciava, ou seja: de não ser suficientemente pornô para fazer jus ao nome, como bem o sintetizaria Jean-Claude Bernadet: "A maior falha dessa pornochanchada não é ser pornô, mas ser muito pouco pornô. Preferível a todas estas sugestões, a esses lençóis medidos, é mostrar os órgãos masculinos e femininos fazendo o que podem fazer." " No entanto, mesmo depois de explicitado o sexo (como iria progressivamente acontecer no fim dos anos 70 e começo dos 80), sexo que certamente não é um valor em si (mesmo em uma sociedade recalcada), restaria a decisiva questão de saber se o tratamento a ele dado era artística ou cinematograficamente eficaz, ou se atrizes (e eventualmente atores) valeriam apenas como corpos nus em exibição. ${ }^{8}$

${ }^{6}$ Entrevista de Paulo Emílio ao jornal Movimento, 19 jan. 1976, citada por ABREU. Boca do lixo: cinema e classes populares, p. 149. Isso obviamente não implica um seu desinteresse por este fenômeno cinematográfico, como bem o atesta sua atenção às reações do público popular destes filmes. Na crítica de Os mansos - segundo José Inacio de Mello Souza - Paulo Emílio “(...) notou as repercussões entre o público, sendo que em '(...) pelo menos duas vezes houve aquela gargalhada unânime, avassaladora, contagiante', indicadora do funcionamento das fórmulas da comédia (em Cassy Jones, o magnifico sedutor, acompanhou o público do Cine Ipiranga na maior parte das vezes em que deu risada').” (SOUZA, 2002, p. 533). E muito menos um seu desapreço por um tratamento mais radical do material erótico, como o tentado por Carlos Reichenbach em Lilian $M$, cujas qualidades são - segundo Paulo Emílio - tão “(...) agudas e insólitas, e indicam tanta personalidade, que por si só obrigam a gente a redobrar o interesse pela carreira de Reichenbach. (...) Já vi três vezes a introdução de Lilian M e meu interesse se aprofunda cada vez mais." (SOUZA, 2002, p. 535).

${ }^{7}$ BERNADET,1979, p. 107, citado por ABREU, 1996, p. 81.

${ }^{8}$ Glauber Rocha, em entrevista ao jornal Movimento (05/07/1976), dizia: "Eu ataco a pornochanchada simplesmente porque os produtores exploram o sexo das mulheres: as mulheres ficam nuas para dar dinheiro. $O$ fato de as mulheres estarem nuas acho ótimo. O fato de as relaçōes sexuais serem mostradas no cinema, ótimo. Isto é um avanço, dentro de uma sociedade recalcada. O aspecto sórdido é como isso é feito: a pornochanchada é uma prostituição audiovisual. (...) Não é justo que uma atriz fique nua, mesmo que ganhe 100 mil cruzeiros, o filme dê 10 milhōes e o produtor ponha tudo no bolso. Aí é que está a exploração da mulher." (ROCHA, 1976, p. 16). 
Antes, porém, de tentarmos definir os elementos da pornochanchada presentes - ou, mais precisamente, apropriados criticamente por Paulo Emílio - em "P III: duas vezes Ela" (conto que fecha Três mulheres de três PPPês), convém afinal apresentar uma primeira e tópica definição do gênero, servindo-nos aqui do estudo sobre a Boca do lixo de Nuno César Abreu:

As pornochanchadas (...) combinavam a influência dos filmes italianos em episódios (que juntavam humor, ironia e malícia em histórias curtas), a tematização dos "dilemas do dar e do comer", que se insinuava nos filmes brasileiros da década de 1960 (e em seus títulos apelativos), e a atualização da comédia carioca popular urbana - a chanchada. A nomeação, certamente elitista, contém algo de pejorativo, procurando assemelhar a comédia erótica dos anos 1970 à chanchada dos anos 1940 e 1950, no sentido de serem filmes sem valor artístico, mal realizados e vulgares. Agregar o prefixo "porno" à chanchada, contudo, não se traduz diretamente em acrescentar pornografia, no sentido transgressivo. (...) O "gênero" servia-se, basicamente, de um erotismo implícito na exibição da nudez feminina e na insinuação de sexo, de títulos com duplo sentido - que ofereciam mais do que tinham para dar -, de situações com peripécias amorosas, piadas cheias de malícia e gags atualizadas da tradição circense. Condensava um imaginário que atingia com precisão o público 'popular'. (...) Na pornochanchada (como na chanchada), podese perceber a assimilação de formas tradicionais de entretenimento popular brasileiro, advindas de esquetes dos teatros de revista, dos espetáculos mambembes, dos circos e, mesmo, do rádio - este já fazendo parte da cultura de massa. Uma dramaturgia que oferece como entretenimento os jogos maliciosos da sedução, da conquista e da performance, filtrados por um tipo de humor construído pela ambigüidade e pelo duplo sentido. ${ }^{9}$

\footnotetext{
${ }^{9}$ ABREU, 2006, p. 142-144. Num depoimento a Jean-Claude Bernadet, Pedro Carlos Rovai observa: "A herança da pornochanchada? A própria chanchada, o teatro de revista, o vodevil. (...) Na chanchada dos anos 50 , já havia tudo o que tem na pornochanchada. A malícia, a frase de duplo sentido, já havia. Numa chanchada dessa época que vi recentemente, tem uma cena que poderia ser de pornochanchada. Ivon Couri, ciumento, ouve a mulher que está num quarto a dizer: tira, põe, aperta; quando ele abre a porta, trata-se de uma agulha. Tudo isso vem do teatro de revista, até do entrudo do Brasil colonial. A pornochanchada, numa sociedade mais permissiva, introduziu a cor, a nudez das mulheres." (ROVAI, 1976, p. 19).
} 
Se voltarmos agora à ficção escrita de Paulo Emílio - e particularmente a "P III: duas vezes Ela" -, cujas relações possíveis (mesmo se oblíquas) com a pornochanchada são um modo indireto e modesto de esboçar a questão da natureza particular do seu cômico erótico (ou obsceno), talvez fosse útil delinear primeiramente o modelo do esquema narrativo dos três contos (exemplificando depois com mais detalhes o último deles), pois neles a reviravolta final (que coincide com um reconhecimento) parece antes trágica, sendo difícil imaginar que o seu efeito pudesse ser o do riso aberto (como pode ocorrer com alguma freqüência em elementos internos à trama). ${ }^{10}$ Roberto Schwarz, por exemplo, descreve sucinta (e criticamente) este esquema narrativo dos três contos na seguinte passagem:

A despeito da muita ironia, o recurso ao suspense como elemento de estrutura é uma solução de facilidade, e é por este lado que o livro confina com o simples divertimento. Com efeito, o plano das três novelas baseia-se na revisão de um acontecimento à luz de uma revelação ulterior que modifica tudo (reprise aliás que está no título das peças: "Duas vezes com Helena", "Ermengarda com H", "Duas vezes Ela"). Na

Ainda dentro deste esteio, deve-se lembrar que (ainda segundo Nuno César Abreu) "a comédia erótica brasileira fixou um conjunto de personagens, a partir de uma galeria de tipos definidos (clichês), em torno dos quais os plots eram desenvolvidos: o machão conquistador sedutor; a virgem cobiçada; a esposa insatisfeita; o homossexual afetado; a prostituta ou garota de programa; o marido pouco atuante; a velha cafetina etc." (ABREU, 2006, p. 145). É preciso, porém, não se esquecer também de que a pornochanchada - extrapolando os limites da comédia erótica (da qual ela nasce e que aqui é o que nos interessa) - “(...) logo se tornou uma definição genérica para filmes brasileiros que recorriam, em suas narrativas, ao erotismo ou apelo sexual, mesmo que fossem melodramas, dramas policiais, de suspense, aventura, horror etc. Assim, 'pornochanchada' passou a designar (indiscriminadamente) um certo modelo de filmes como se fosse um gênero.” (ABREU, 2006, p. 140).

${ }^{10}$ A não ser que admitamos com Roberto Schwarz um sutil riso final - em que o leitor se identificaria com o irônico autor e não com o patético narrador - que viria do fato de que na reviravolta e revelação final "a personagem retoma contato com o seu movimento profundo, e chega a uma decisão, a qual nos três casos é uma bobagem. Noutras palavras, a despeito das peripécias, das revelaçōes e da intensidade da conclusão, a melodia não vai mais longe, em fim de contas, que todo mundo. Trata-se de uma paródia da opção existencial, e a combinação de autenticidade pessoal e tolice é um achado." (SCHWARZ, 2007, p. 145). 
primeira novela o adultério dos vinte e cinco é revisto aos cinqüenta, mas acrescentando um elemento novo: atrás do encontro com Helena havia estado a intenção do marido. Na segunda, a vida é reconsiderada à luz das revelaçôes comoventes do diário roxo, as quais por sua vez serão revistas à luz das revelações acabrunhantes do diário azul. Na terceira, finalmente, a fase feliz do matrimônio, registrada no primeiro caderno, é retomada à luz de sua fase turbulenta, registrada no segundo. ${ }^{11}$

Ora, redefinindo com mais precisão os resumos-esquemas de Roberto Schwarz, poderíamos descrever a reviravolta e tomada de consciência final nos três contos (ou novelas) da seguinte maneira (em que a um elemento cômicoerótico se segue um outro, trágico e final): no primeiro, a suposta traição com a mulher do mestre se revela uma artimanha calculada (não sem alguma graça erótica) por este último, que usa o narrador (e discípulo) como meio de conceber um filho em sua mulher, mas isso representa para o narrador a perda definitiva da amizade do mestre (e do amor de Helena), assim como - no instante da revelação - os quase simultâneos ganho e perda trágica de um filho que ele jamais poderá conhecer pessoalmente; ${ }^{12}$ no segundo, o caderno azul (após o roxo o haver disposto para o perdão) revela o narrador como múltiplo e estúpido corno dos adultérios de Hermengarda (que, no

${ }^{11}$ SCHWARZ, 2007, p. 143. Ver também Alexandre Eulálio: “Todos os contos possuem certa peripécia que inverte $\mathrm{o}$ aparente andamento normal da narrativa e culminam praticamente com a tomada de consciência - extremamente melancólica no segundo conto e dramática no primeiro-, com um desmascaramento do personagem que parece ascender a um mínimo de consciência ainda confusa." (EULÁLIO, 2007, p. 156). EModesto Carone (que, na seqüência, descreverá com algum cuidado a armação narrativa dos três contos): "Sua narrativa parece, de fato, sustentar a acuidade do conhecimento no molejo de ninharias e surpresas cujo resultado é sempre uma estonteante virada de opinião. Vale a pena acentuar que seus três contos tematizam a revisão inesperada de uma experiência - invariavelmente a que se processa entre o narrador e uma mulher, como indica o título do livro num trocadilho que à primeira vista soa estranho." (CARONE, 2007, p. 151).

12 "Meu pensamento abandonou logo a face patética de Helena e a figura trágica do mestre para se concentrar no filho que durante um tempo tão curto eu ganhara e perdera. A sinopse esquelética da vida de meu filho com o nascimento, estudos, amor, luta, martírio e morte, lançou sobre a minha vida um vazio imenso que só sua lembrança poderia preencher." (GOMES, 2007, p. 36). 
entanto, ainda precisava do dinheiro e afeto dele e, por isso, arma o caderno roxo), mas este reconhecimento pressupõe a morte acidental e trágica de Hermengarda que, por sua vez, só é reconhecida por ele tardiamente, deixando-lhe (após a dor do luto) apenas a sensação final de total arruinamento; ${ }^{13}$ no terceiro, a confissão de Ela (que, na exacerbada crise conjugal, visa a uma solução prática: o desquite) revela ainda uma vez (mas agora com requintes de prazer e crueldade) o marido traído, agora por uma sacana Ela que dá (como sempre deu) por trás para o coetâneo primo e pela frente para o também já envelhecido doutor Bulhões (que a desvirginou e lhe reconstituiu a virgindade), mas aqui a própria revelação da estória causa por sua comicidade uma convulsão de riso no narrador que enfurece Ela, levandoa a xingá-lo chulamente e o que é pior - a pronunciar (objeto máximo de horror e repulsa) o seu nome próprio, o que o leva, em violenta reação contrária, a dar um soco em sua cara (arrancando-lhe sangue da boca e das narinas e quebrando seus dentes), o que para ele implicará certamente não só um financeiramente desastroso desquite litigioso (com conseqüências desastrosas também para a sua reputação em seu círculo familiar) mas também na perda trágica final - quase simultânea à descoberta - da única Ela que ele "poderia ter verdadeiramente amado" (ou seja: a amante anal do primo, única capaz de dizer com "uma tonalidade juvenil" de voz, que é "vulgar mas cristalina": "Vá tomar no cu, Polydoro!"). ${ }^{14}$

\footnotetext{
13 "A descoberta tranqüilizadora [i. e. do sofrimento] me salvou do pânico e me levou a um choro manso que me orientou com cuidado, evitando erros e tropeços, para a sua motivação: Hermengarda morrera. O choro tranqüilo durou o tempo que quis, sem soluços, sem sons e pouca lágrima. (...) Quando o pranto estancou e consegui olhar fora de mim, não sobrara pedra sobre pedra na casa, no bairro, em São Paulo, no mundo. O universo virara pó.” (GOMES, 2007, p. 85).

14 "No instante em que me dirigiu os palavrôes, aquela voz inteiramente nova desvendou a existência de uma Ela diversa de todas que conheci (...). A nova Ela era a do primo, potencialmente intacta dentro das outras, reprimindo-se para mim e reprimida por mim, a única que eu poderia ter verdadeiramente amado: a Ela da Quarta Parada, moleca de maus bofes, língua viva e voz tintinabulante, a Ela que eu conhecera um segundo antes de pronunciar o único palavrão insuportável, meu nome, e partir para sempre, os dentes quebrados pelo meu soco." (GOMES, 2007, p. 115).
} 
O comentário mais detido de Modesto Carone - cujo resumo do primeiro conto aponta também para um desenlace trágico ${ }^{15}$ - ao desfecho do último conto - após um resumo mais detalhado de sua estória (que não retomarei aqui) - aclara bem o limite imposto ao cômico-erótico por um esquema narrativo cuja solução final, como já foi dito, nos parece antes trágica e grave (tornando muito improvável no fim da estória o efeito de um riso solto imediato):

O inesperado da situação interrompe o curso espirituoso e complacente de uma narrativa que já vinha se gastando em humor e savoir-faire. É neste quadro de referências que, aproveitando-se do susto, o autor promove a reversão de expectativas que se apodera de leitor e narrador, submetendoos a um incisivo choque de conhecimento. Pois através da cena grotesca o aristocrata falante do conto perde o verniz e adere à barbárie até então encoberta pelo bom-tom de um discurso safado. Mas o clímax mostra-se também propício a revelaçôes de outra ordem - e assim ficamos sabendo, através de Polydoro, que só nessa hora ele consegue ver a esposa como a moleca desbocada da Quarta Parada que poderia ter amado, ao seu modo meio degenerado, se justamente não a tivesse perdido para sempre. ${ }^{16}$

Feito, como era necessário, este primeiro enquadramento narrativo bem atento aos desfechos trágicos dos três contos, podemos enfim voltar aos elementos cômico-eróticos presentes nas três estórias de Três mulheres de três PPPês e especialmente na última. Na primeira, o adultério em Campos do Jordão (que se revela como o episódio programado da concepção do filho) dura quadro dias e quatro noites, sendo descrito abertamente mas sem vulgaridade o modo das relações sexuais (ou mais precisamente da cópula): "Não que Helena fosse propriamente insaciável, mas se empenhava com ardor em provocar o meu gozo o mais rapidamente possível, quantas vezes pudesse." ${ }^{17} \mathrm{Na}$ versão reveladora de Helena, por sua vez, este modo é descrito jocosamente como uma técnica concepcional pensada analogicamente por

\footnotetext{
15 'No primeiro deles, de certa forma o mais 'romântico', o narrador artrítico descobre, com trinta anos de atraso, que tinha sido envolvido à revelia num jogo erótico aparentemente hilariante, mas no fundo perverso, de que todo mundo saiu perdendo - incluindo-se na perda a vida de um filho." (CARONE, 2007, p. 151).

${ }^{16}$ CARONE, 2007, p. 152.

${ }^{17}$ GOMES, 2007, p. 15.
} 
ela: "Sou filha e neta de fazendeiros, passei a infância em meio de cavalos e touros e com surpresa li na tradução espanhola de um livro escandinavo a descrição ilustrada de um método que se assemelhava muito às manipulaçóes a que são submetidos os garanhões para facilitar e abreviar sua função." ${ }^{18}$ Mas é no jantar da primeira noite que se concentra o decisivo jogo erótico da sedução (cuja preparação meticulosa, como saberemos depois por Helena, tem vários acentos cômicos) que inclui, num divertido conjunto bem idiossincrático, o agudo decote do vestido (que alonga o pescoço), o pato assado com laranja (canard aux oranges), o abundante vinho francês, a mostra do começo da gengiva superior de Helena quando sorria, o creme de caramelos e, enfim, um champanhe especial de Reims. O que, no entanto, é marcadamente cômico e obsceno, já no próprio relato do narrador, é a incontrolável ereção (de seu membro viril) acionada pelo riso de Helena, "com um nadinha de gengiva na parte superior" (característica comum das moças que mais o atraíam), ereção ratificada pelo creme de caramelos (sobremesa preferida da mais atraente de suas amantes) que o leva à cozinha na hora do café:

Ao provar o creme de caramelos a ereção não mais me aborrecia. Era bem-vinda. Um resto de consciência me apaziguava dizendo que efetivamente nada fazia de mal enquanto uma ponta de embriaguez ironizava o liberalão que tolerava tudo. Me dispus a ajudar Helena a preparar o café e ela ria, ria da minha falta de jeito. Na verdade, de pé, me sentia mais desajeitado do que anteriormente. As cuecas e calças de 1940 tinham a folga que impedia ao mesmo tempo liberar ou disciplinar a ereção. Aquele olhar que partia da altura de minha cabeça e para evitar meu rosto percorria os lados e o baixo do meu corpo, corria o risco de se fixar numa grossura capaz de anular o encantamento daquele instante. ${ }^{19}$

$\mathrm{Na}$ segunda estória, a maior das três, apesar de uma referência rápida à primeira relação sexual com Hermengarda, ${ }^{20}$ não encontramos - como nas

${ }^{18}$ GOMES, 2007, p. 27-28.

${ }^{19}$ GOMES, 2007, p. 14.

20 "Logo que nos conhecemos, quando pela primeira vez a possuí, confessei-lhe esse nome numa retribuição à confiança que tivera na minha palavra, me acompanhando ao leito antes de ver assegurada uma situação definida." (GOMES, 2007, p. 40). 
outras duas - nenhuma descrição mais detida e picante de uma noite de amor, com detalhes sobre o modo de conjunção carnal, pois a própria trama (com seu clima mais pesado de guerra conjugal) parece dispensá-lo. Mas um elemento cômico-erótico está visivelmente presente no modo da descoberta tardia pelo narrador (apenas quando da primeira e aleatória leitura do caderno azul) de que fora traído pela mulher (com o dentista e com vários outros parceiros que freqüentavam sua casa), ou seja: pelo reconhecimento de um hilário lapso de leitura que, à maneira de um jogo de palavras, opera uma substituição de uma consoante por outra no corpo de uma mesma palavra:

Abri-o meio ao acaso, disposto a juntá-lo ao resto quando meu olhar caiu numa linha onde perto do nome de Cincin havia uma referência ao sabonete de eucalipto. Li a passagem e fiquei sabendo que os banhos tinham sido sugeridos por Cincinato. (...) Ao mover a cabeça, meus olhos abrangeram uma frase cuja última palavra me esbofeteou: "Só mesmo um corpo como Polydoro". O golpe me fechou os olhos. Nunca o nome execrado me agredira de forma tão traiçoeira. (...) Me veio a esperança de um erro de leitura, a frase parecia nem ter sentido. Abri os olhos e fui reto à última palavra. (...) Reli a frase e descobri com efeito uma palavra que dificultara a compreensão. Lera um $p$ ao invés de $n$, não era corpo que estava escrito mas corno: "Só mesmo um corno como Polydoro". ${ }^{21}$

Esta revelação inesperada o motiva a uma leitura cuidadosa do caderno azul e à descoberta de uma série insólita de amantes de uma inverossimilmente adúltera e promíscua Hermengarda (que até mesmo se deita simultaneamente com dois rapazes):

A quantidade de coisa que fiquei sabendo foi prodigiosa. Cincinato recomendara, de fato, os banhos com perfume de eucalipto e o conselho nada tinha de desinteressado porque fora durante meses amante de Ermengarda. (...) Ermengarda praticamente o expulsou da cama quando

${ }^{21}$ GOMES, 2007, p. 76. A atenção a esta palavra algo vulgar, mas essencial a um enredo típico de marido traído, é prenunciada em uma engraçada observação vocabular do narrador, ao falar do detetive particular contratado por Hermengarda e depois por ele também: "Apesar de mal pago, preferia trabalhar por conta de cornos e mulheres ciumentas. Devo a esse funcionário pouco bafejado pela sorte a informação de que o feminino de corno não é usual." (GOMES, 2007, p. 52). 
ele lhe pediu uma forte soma para modernizar o consultório. Ficou indignada achando que o dentista queria bancar o gigolô (...). (...) Com os moços Alfredo e Pradinho, o comportamento de Ermengarda foi diverso. Corrompeu os afilhados oferecendo-lhes a cigarreira e as abotoaduras de ouro que ela própria me oferecera em meus aniversários. Não contente com isso, recebia-os juntos na cama, fazendo perigar ainda mais a formação desses jovens componentes da nossa melhor reserva moral. Mas a mulher não ficou por aí. Passou por Robert, o espião americano. Passou pelo cônsul do Paraguai e até pelo do Haiti. ${ }^{22}$

$\mathrm{Na}$ terceira estória, no entanto, diferentemente das duas primeiras, além do uso mais evidente e axial (à trama) do duplo sentido e dos jogos de palavras com caráter obsceno (sobretudo na segunda e particular nomeação, por Ela, do narrador Polydoro e do amante doutor Bulhões), é o conjunto da própria trama - revelada afinal pela surpreendente confissão de Ela - que se articula cômico-eroticamente (com despudorados e "baixos" elementos perversos), tal como é explicitado pelo próprio narrador, ao repensar ${ }^{23} \mathrm{e}$ resumir a estória agora contada por Ela e descrever o transmutador efeito dionisíaco que esta lhe desperta:

Ao resumir mentalmente o que ela me contara, percebi que o esqueleto do enredo era a história de uma moça que sai virgem de bruços e debaixo dos membros superiores, inferiores e médio de um primeiro homem, para ser desvirginizada duas vezes por um segundo a fim de se tornar esposa de um terceiro. Encontrei uma tal semelhança com as brincadeiras verbais em voga no Liceu ou nas conversas inconseqüentes da Cidade

\footnotetext{
${ }^{22}$ GOMES, 2007, p. 76-77. No quadro do que o narrador chama amargamente de impaciência de Hermengarda para com ele - no contexto mais livre do caderno azul - e especialmente para com a sua irritante não-percepção do caderno roxo, ela define a lentidão de seu espírito com uma imagem zoológica tradicional que, por meio do significante usado, se desloca jocosa e trocadilhescamente para uma pouco edificante e engraçadíssima imagem escatológica: "Minha lentidão era um recorde absoluto, ganharia qualquer corrida de cágados ou dos com acento no segundo $a$." (GOMES, 2007, p. 80)

23 "Esforcei-me para abranger o conjunto da sua narrativa e a nova situação criada, repassei os principais temas, fiz ajustes e reajustes, procurando pesar tudo de maneira objetiva, com o máximo de honestidade para comigo e para com ela. (...) desta vez o que se salientava não era mais o lado patético mas a comicidade da maior parte das situações." (GOMES, 2007, p. 113).
} 
de München, do Rutli e do Franciscano, que mergulhei na adolescência e arrebentei todas as comportas da maturidade. $\mathrm{O}$ resultado da explosão foi literalmente um ataque de riso que me estendeu de comprido na poltrona, sacudido por intermináveis gargalhadas que ameaçaram me sufocar, chorando de alegria até o limite da convulsão. ${ }^{24}$

Este delicioso clímax ao avesso não é, porém (como já indicado), o fim da totalidade da narrativa, e nem o ponto de vista do narrador coincide sempre necessariamente com o do autor (que, muito antes pelo contrário, parece o mais das vezes criticá-lo ferinamente), contudo apenas através do discurso do narrador (que, sendo o de uma personagem, de algum modo engloba o das outras personagens) pode o autor (que não tem discurso próprio separado) manifestar sua irônica inteligência crítica, ${ }^{25}$ numa superposição incômoda cujo efeito, quando bem percebida, é a inverossimilhança. ${ }^{26}$ Roberto Schwarz irá defini-la, num primeiro momento, da seguinte e negativa maneira: "No plano da verossimilhança elementar, é talvez um defeito, com repercussões: a proximidade da piada é excessiva, e persegue um pouco a leitura." 27 Ora, especialmente no caso do terceiro conto, esta "excessiva proximidade da piada" é certamente deliberada (e estruturante) e não envergonharia nem estética nem moralmente Paulo Emílio, que - de algum modo se identificando com a condição de velho do narrador ${ }^{28}$ poderia muito bem encampar (já que, como bem viu R. Schwarz, “(...) 'eu' é um outro - mas só até certo ponto") sua crítica à pretensa e insossa seriedade

\footnotetext{
${ }^{24}$ GOMES, 2007, p. 114.
}

25 "Seu convencionalismo está entretecido com a prosa esplendidamente desabusada e flexível do Autor, que paira como uma enorme risada sobre a estreiteza do assunto e a obviedade dos andaimes narrativos (...). Essa mesma distância aparece no interior do estilo. O pastiche reúne à elegância uma dimensão cara-de-pau, de farsa grossa, que é do melhor efeito." (SCHWARZ, 2007, p. 125-126).

26 "Entre a limitação das personagens e a inteligência de sua escrita o desacordo é total, e a conjunção éforçada. Este é o X estético do livro.” (SCHWARZ, 2007, p. 128. Os itálicos são do próprio autor do ensaio.).

${ }^{27}$ SCHWARZ, 2007, p. 128.

28 "Uma segunda geração foi conquistada na década seguinte (à de 60) entre os alunos da ECA, sendo chamados, então, de 'os jovens' em oposição a um Paulo Emílio aceitando ainda assinar 'o velho', como fizera antes." (SOUZA, 2002, p. 564). 
da idade madura (composta por trabalho e família) e sua adesão libertária e nostálgica à inconseqüência e gratuidade da graça cômica na adolescência (acionada, em ambientes mundanos, pelo álcool), ${ }^{29}$ cujas brincadeiras verbais têm (precisamente como este conto) como objeto preferencial o sexo.

Como já vimos, não é o sexo (ou a pornografia) em si - mas antes sua ausência quando tão anunciado - o que incomoda Paulo Emílio na pornochanchada. O que nela resta de sexo (ainda que o tratamento deste seja inadequado e jamais tenha a contundência cômica desabrida do de "P III: duas vezes Ela"), sobretudo em uma sociedade reprimida e falsamente moralista como a brasileira sob a ditadura militar no começo dos anos 1970, é apreciado positivamente e sem nenhuma falsa vergonha por Paulo Emílio, que coincidentemente o associa (como se resgatando sua vitalidade) com a adolescência, em conhecida passagem sobre a pornochanchada do célebre ensaio "Cinema: trajetória no subdesenvolvimento" (mais ou menos contemporâneo à composição de Três mulheres de três PPPês):

O estilo é próximo dos documentos publicitários cheios de fartura, ornamentados por imagens fotogenicamente positivas do ocupado e pelo bamboleio amável de quadris nas praias da moda, combinadas ao louvor de autoridades militares e civis. Essa simultaneidade visual um pouco insólita não significa que um setor qualquer do poder público tenha inspirado - dentro da fórmula de que hoje o circo complementar do pão é o sexo - o erotismo que irrompeu no cinema brasileiro de uns anos para cá. (...) O erotismo desses filmes, apesar do afobamento, da vulgaridade ineficaz, da tendência autodestruidora em acentuar nos quadris as nádegas e no seio a mama, é com efeito o que têm de mais verdadeiro, particularmente quando retratam a obsessão sexual da adolescência. ${ }^{30}$

Aquilo - em que eles (eternos adolescentes) e Ela só pensam - está de fato no centro dos dois eventos decisivos e sucessivos que, como reveladores, mobilizam e articulam toda uma trama erótico-cômica (ou pornocômica):

29 "Fui um moço divertido, com sucesso na escola e nas cervejarias do São Paulo antigo. Mudei muito, mas atrás da severidade que os negócios e as conveniências impōem, guardei alguns traços da alegria passada. Aparentemente acumulei as risadas não dadas pois desde que saí dos vinte anos só conheci no trabalho ou em casa situações que me constrangiam à austeridade." (GOMES, 2007, p. 113-114).

${ }^{30}$ GOMES, 1996, p. 106-107. 
a lua de mel fracassada do narrador Polydoro (no ato da "defloração") com a talvez excessivamente revirginizada (pelo ginecologista e amante doutor Bulhões) Ela, e a relativa "re-desvirginização" natural (e não com o bisturi) de Ela (pois sobrara um ponto, após a primeira e insatisfatória noite com Polydoro) pelo intrépido doutor Bulhões, durante uma prolongada consulta ou "pequena cirurgia", que irá permitir enfim que se consuma plenamente o ato sexual entre os agora casados Polydoro e a "virgem" (ma non troppo) Ela. Extrapolando este primeiro quadro de um transgressor e atraente desvio etário (de um doutor Bulhôes maduro desvirginando Ela adolescente com dezesseis anos, ou de um Polydoro já bem velho e excitado tendo dificuldades pra "desvirginar" Ela, já com seus trinta anos, revirginizada cirurgicamente pelo doutor Bulhões), também aquilo, mas agora especificado como o "desvio" preferencial do sexo entre heterossexuais, ou seja: o pornograficamente celebradíssimo sexo anal (cf. do ponto de vista feminino, $A$ entrega de Toni Bentley), está no centro não de um evento particular mas de toda uma relação apaixonada desde a infância com o verdadeiro e coetâneo amante anal: o primo, Ele que, juntamente com Ela, é o grande beneficiário de seu desquite agora litigioso com Polydoro.

O modelo desta relação de Ela com seus dois amantes (o primo e o doutor Bulhões) e seu marido (Polydoro) - relação simultânea, isto é: de um mesmo período de tempo, apesar de não ser propriamente um ménage à quatre - é descrito, discutido e nomeado com jocoso cuidado pela própria narrativa como a de uma poliandra, substantivo feminino não-dicionarizado que designaria uma "mulher de muitos homens', e também como uma diarquia, ou seja: como uma soberania dividida e diferenciada que se exerce sobre dois territórios distintos (do corpo de Ela): a vagina (doutor Bulhōes e Polydoro) e o ânus (o primo). Mas este modelo (já bem pouco normativo), como esclarece o próprio narrador, é apenas o apresentado pela confissão de Ela, pois ela ainda poderia ter tido outros homens não citados em seu relato (o que ampliaria e diversificaria sua traição, rebaixando ainda mais o até então crédulo marido):

Quisera saber se nós três tínhamos sido os únicos homens importantes de sua vida ou se ainda restavam outros. Fiz bem em resistir à curiosidade. A introdução de novas personagens faria com que a história corresse o rico de se tornar fastidiosa e, em última análise, menos respeitável. ${ }^{31}$

${ }^{31}$ GOMES, 2007, p. 111. 
Ainda que enquadrável também em um possível filão tradicional da comédia erótica (e da pornochanchada): o da traição ao marido cretino, o que este modelo, no entanto, acentua é um deslocamento ou inversão (nada habitual em uma sociedade - e também em um gênero como a pornochanchada basicamente machista) nas relações de poder entre homem e mulher: aqui é Ela quem (deixando obviamente a posição de objeto para a de um sujeito inteligente e ativo em suas manipulações) tem muitos homens e detém o controle da situação. Esta atenção à assim configurada mulher (cujo fascínio erótico vem também de uma certa malignidade) parece estar no centro de todo este empreendimento ficcional de Paulo Emílio, tal como o sugere uma frase do autor incluída num breve texto de apresentação desta sua obra por Zulmira Ribeiro Tavares: "E, dominando tudo, Helena, Hermengarda e Ela, três mulheres totalmente for do controle de seus respectivos PPPês." ${ }^{22}$ Segundo a revelação de Zulmira: "Ao levar o texto acima para conhecimento de Paulo Emílio, ele exclamou algo assim: 'Mas, e as mulherinhas!? Você não diz nada sobre as mulherinhas!' Eu lhe respondi: 'Diga você'. O que ele fez." 33

Assim como o enredo (que tem como objeto tradicional os adultérios e a crise conjugal) também as personagens de "P III: duas vezes Ela" podem ser pensadas como deslocamentos ou recombinaçôes irônicas de tipos facilmente localizáveis na galeria da pornochanchada ${ }^{34}$ (e eventualmente

32 TAVARES, 2007, p. 119.

${ }^{33}$ TAVARES, 2007, p. 119, nota estabelecida por Carlos Augusto Calil.

${ }^{34}$ Cf. GARDNIER, s. d., p. 1-4. Antes de introduzir uma galeria mínima de tipos (com suas nomeaçōes e definiçōes básicas: "o garanhão cafajeste", "a virgem profissional", "o velho tarado", "a frígida gostosa”, "a moça liberada", "o marido inadimplente", "a esposa em erupção", "a titia malandrona", "o safado engravatado"), Ruy Gardnier faz a seguinte introdução básica ao tema: "Como todo gênero, a pornochanchada também erigiu seus personagens típicos. (...) Ancorou-se em personagens nossos, muito nossos, comuns na vida doméstica brasileira (...). Aproveitando-se de não precisar de crivo moral, esse gênero sempre tão mal olhado e pouco estudado pôde dar livre vazão a tudo que não era de bom tom e de que todavia o país sempre esteve cheio: machismo, assédio dentro da empresa, sexo como ascendência social ou moeda de troca, recalque sexual tanto de mulheres como de homens (...)."(Idem, p. 1). Eis a (em parte já citada) definição sintética e nomeação dos tipos por Nuno César Abreu: "A comédia erótica brasileira fixou um conjunto de personagens, a partir de uma galeria de tipos definidos (clichês), em torno dos quais os plots eram desenvolvidos: o machão conquistador sedutor; a virgem cobiçada; a esposa insatisfeita; o homossexual afetado; a prostituta ou garota de 
também da comédia erótica leve): Polydoro figura, num primeiro momento, uma espécie comedida de "velho tarado" (doido apenas para desvirginar a jovem noiva) e, num segundo, uma espécie - no caso, definida basicamente pela velhice - de "marido inadimplente"; enquanto Ela figura, num primeiro momento, uma espécie fake e dissimulada de "virgem profissional" 35 (para a qual a virgindade - verdadeiro fetiche da moral sexual burguesa - é condição para o casamento, por sua vez meio costumeiro de ascensão social) e, num segundo, quando revelada a falsa virgindade e a sua dupla e diferenciada iniciação sexual (com o primo por trás e com o doutor Bulhões pela frente), como uma espécie inteligentemente hipócrita de "moça (e depois mulher) liberada"; enfim o doutor Bulhões figura, num primeiro momento, uma variante médica (ou, mais pontual e tipicamente, ginecológica) de "safado engravatado" ${ }^{36} \mathrm{e}$, num segundo, uma espécie mais adequada (mas também triste) de "velho tarado". Enfim, na própria renomeação dos protagonistas Polydoro e doutor Bulhões por Ela (que aí exerce soberana sua sagacidade e malícia discursiva) com jogos de palavras lisonjeiros que remetem direta ou indiretamente a um sempre facilmente reconhecível segundo sentido obsceno (o órgão sexual masculino), "P III: duas vezes Ela" se aproxima (mas procedendo obviamente com sutileza e maestria outras) das nomeações e duplos sentidos jocosos e cômico-obscenos tão comuns na pornochanchada.

programa; o marido pouco atuante; a velha cafetina etc." (ABREU, 2006, p. 145). Ou a ainda mais rápida da História do cinema brasileiro organizada por Fernão Ramos: "Uma galeria de figuras, como o paquerador e o play-boy, o marido traído, a virgem, a viúva disponível e fonte de secreta sexualidade e o homossexual perambulam pelas produçóes." (RAMOS, 1987, p. 406).

${ }^{35}$ Ruy Gardnier, após citar os filmes Ainda agarro essa vizinha e A viúva virgem, lembra de um tipo - apesar das óbvias diferenças - mais próximo ao de Ela: "Em Pintando o sexo, uma espécie diferente de virgem profissional surge: a autoconsciente." (GARDNIER, s. d., p. 2) Como exemplo de provocação, que ao mesmo tempo testemunha uma certa atenção, lembramos - com José Inácio de Melo e Souza - a pergunta que Paulo Emílio fez à seríssima Maria Hermínia Tavares numa reunião do comitê da revista Argumento: "A senhora assistiu, por acaso, A viúva virgem?..." (SOUZA, 2002, p. 530).

${ }^{36}$ Ruy Gardnier lembra em um episódio de Um uisque antes e um cigarro depois de um tipo análogo ao do doutor Bulhōes: "Em outro episódio do filme, um advogado recebe uma cliente que diz ter sido seduzida e desvirginada pelo noivo. Sendo maior de idade, diz o advogado, não resta a ela nenhum tipo de ação na justiça. Porém, ele está interessado em outra coisa: em ser o segundo sedutor da menina." (GARDNIER, s. d., p. 4). 
Na nomeação (por Ela) de Polydoro - nome execrado pelo personagem-narrador e cuja enunciação tem um papel decisivo no desfecho (como bem deixa ver a última frase do conto) - há uma alusão, jamais inteiramente explicitada (e cuja adivinhação é um prazer que mantém o sorriso alerta), ao órgão masculino reconhecido pela excelência de suas performances sexuais ("pau de ouro"), sendo portanto o novo nome uma espécie de transição matreira e "chique" entre as duas nomeações simultaneamente encobertas e aludidas (Polydoro e pau de ouro) por ele: Paul Dior. Mas a graça que se perde com este resumo rapidinho e afoito (na decifração) pode ser recuperada em parte por um recorte longo da descrição linguisticamente precisa e progressivamente reveladora do narrador (onde também o modo cômico-obsceno ágil e sutilmente sacana de Paulo Emílio se manifesta plenamente):

$\mathrm{Na}$ terceira noite de nosso casamento, Ela me deu afinal uma denominação que ficou. Achei-a extremamente suave, sem compreender de início seu significado. Soava aproximadamente como pauldior, pronunciado bem à francesa. Dito baixinho durante as carícias parecia um daqueles complementos eróticos verbais que aprendera em seus cursos e cuja gratuidade é bem conhecida dos especialistas. Na manhã seguinte, porém, na hora do café e dos jornais, ela continuou a emitir as mesmas envolventes sílabas noturnas. (...) Estava naturalmente aludindo, lisonjeira, aos acontecimentos da noite anterior e comecei a responder aos pauldior com as expressóes minha mulherzinha ou meu mulherão, as únicas que minha criatividade fornece (...). Agastada em seu pudor, ela estranhou as palavras inadequadas para aquela hora, perto da criadagem maliciosa e malintencionada, rondando por perto, os ouvidos talvez colados à porta. Só então percebi que há mais de oito horas estava me chamando pelo nome. (...) Na boca de Ela os sons que tanto me fizeram sofrer ficaram sendo uma fonte de prazer. Na verdade, os sons eram outros, pois dizia as quatro sílabas de maneira irreconhecível para terceiros, sobretudo para os criados. As duas primeiras quase viravam Paul, nome bonito em qualquer língua e suficientemente afastado da combinação po-ly. Sua pronúncia alterava ainda mais as duas outras sílabas, do-ro. Insinuava entre o $d$ e o $o$ um $i$ acariciante que praticamente anulava o $o$ final, de forma que se ouvia claramente Dior. Como por outro lado separava com rápido intervalo as duas primeiras sílabas das outras, eu 
ganhava nome e sobrenome novos Paul Dior - tão lisonjeiro ao lado francês de minha personalidade. ${ }^{37}$

Que a ocasião nos permita agora uma breve digressão etimológica. A questão (reiterada pela narrativa) do nome próprio (do narrador) Polydoro é decisiva não só para "P III: duas vezes Ela" (onde Ela também como nome próprio - em sua irônica designação indiferenciada e genérica do feminino - constitui uma questão) mas para o conjunto de Três mulheres de três PPPs. A crítica, no entanto, apenas aflorou a questão. José Inacio de Melo Souza sugere dubidativamente a seguinte e hermética referência cinematográfica: "Polydoro, o nome odiado talvez tirado de um cômico italiano do cinema mudo (Polydor/Polidoro, personagem encarnado pelo ator francês Ferdinand Guillaume), (...)", ${ }^{38}$ enquanto Alexandre Eulálio, com mais efetividade, se pergunta elementarmente pelo sentido do nome e por sua relação com a personagem no conjunto das estórias: "Não se pode esquecer que Polydoro significa em grego 'generoso', rico em dons, múltiplo de presentes etc. Uma ironia, pois o personagem é extremamente mesquinho, contrariando o significado do próprio nome." ${ }^{39}$ É certo que nesta leitura Alexandre Eulálio minimiza um sentido possível do nome a partir do adjetivo grego polýdôros, que quer dizer também, segundo o Dictionnaire étymologique de langue grecque de Pierre Chantraine, "que custou muitos presentes", ${ }^{40}$ mas o sentido enfatizado - "que traz muitos dons", segundo o Chantraine, ou, segundo o Greek-English Lexicon de Liddell-Scott, "de mão aberta" ${ }^{41}$ - continua a ser o mais plausível, ainda que (ou porque) em conjunção díspar com o ser da personagem. Acreditando ser inútil, no caso, relembrar o Polydoro filho de Cadmo e pai de Lábdaco (o avô de Édipo) ou o filho de Príamo, morto por Aquiles na versão da Ilíada ${ }^{42}$ gostaríamos apenas de - a partir do sentido básico sugerido por Alexandre Eulálio - fazer uma inflexão jocosa de leitura

\footnotetext{
${ }^{37}$ GOMES, 2007, p. 92-93.

${ }^{38}$ SOUZA, 2002, p. 558.

${ }^{39}$ EULÁLIO, 2007, p. 155.

${ }^{40}$ CHANTRAINE, 1983, v. 1-2, p. 280.

${ }^{41}$ LIDDEL; SCOTT, 1977, p. 1438.

${ }^{42}$ Cf. GRIMAL, 1951, p. 384.
} 
do nome (inversa à da leitura final de Alexandre Eulálio) com conotações obscenas que agora evidenciariam o caráter passivo e de objeto da personagem (numa cômica inversão de papel com as mulheres): Polydoro, "o que dá muito" ou, traduzindo em linguagem chula, "o que é comido por muitas".

Já a renomeação (por Ela) do doutor Bulhôes opera por meio da substituição (por sua vizinha no alfabeto) da consoante inicial do nome, expondo diretamente no novo nome criado um termo chulo (dicionarizado como "colhôes") que designa "os testículos" e pode conotar "coragem e audácia viris" também no plano erótico, atuando portanto como um envaidecedor elogio. Eis mais uma vez um recorte seqüencial de trechos da narrativa que revelam aos poucos e muito comicamente - jogando com a hesitação ou ambigüidade calculadas da pronúncia do nome por Ela (assim como com notações gráficas) - o novo e chulo nome próprio (mas que tem o ar de um sobrenome) brincalhonamente forjado, até que ela o adote plena e desavergonhadamente:

Nessa altura, ela já dissera algumas vezes o nome do médico mas só percebi isso depois. Levei algum tempo para reconhecer numa sonoridade um pouco vaga o nome de Bulhôes. Ela o pronunciava sem o título e praticamente engolia a primeira letra de maneira que eu não atinava com a significação dos ...ulhões que começaram a aparecer com certa freqüência. (...) Nesse abandono, o nome ?ulhôes readquiriu uma consoante que não correspondia à original e cuja motivação me intrigou até o momento em que o relato a esclareceu. Quando se acordava de mim, Ela criava um som ambíguo que pertencia simultaneamente às duas primeiras consoantes do alfabeto. (...) [Fala de Ela para Polydoro] 'Você não o conheceu, não quis conhecer de maneira que não pode fazer uma idéia de suas pestanas. Lembram, na abundância, as daquele escritor, você me mostrou o retrato na biblioteca ao lado do teatro Leopoldo Fróes, com a diferença de que aquele homem era feio e B/Culhões era muito bonito. (...) Não quero ser injusta com ninguém. Vocês foram os dois homens da minha vida e enquanto fui feliz, acho que pude ser eqüitativa com ambos, pelo menos me esforcei. Vou dar um exemplo: Bulhões sabia que eu te chamava de Paul Dior e pediu que lhe desse a mesma prova de carinho transformando também seu nome. Perguntei-lhe se também não gostava do seu e ele disse que embirrava com o $B$ e acrescentou rindo que preferia a consoante vizinha. Daí por diante, como Paul Dior para você, foi esse o nome pelo qual sempre o chamei, de portas fechadas, é claro, longe das enfermeiras 
e dos assistentes do consultório, da Santa Casa, da Beneficência Portuguesa, da Casa de Saúde Matarazzo e do Hospital das Clínicas (...), lugares onde trabalhava e serviam aos nossos encontros. ${ }^{43}$

Não mais na esfera da nomeação (reinventada) de personagens, mas na de uma cena estática representada por uma gravura, atua ainda o recurso cômico a um segundo sentido obsceno facilmente detectável (uma designação chula do órgão sexual masculino). Mas o lazer algo vazio, que torna possível a descoberta e contemplação desta repetidamente citada cena (em um bar/padaria da provinciana Águas de São Pedro cujo nome brinca jocosamente com o gênero gramatical de um substantivo que em língua portuguesa nomeia o prazer intenso), emerge como um fundo triste (e, a seu modo, ridículo) que delineia o modo de vida burguês amortecido da velhice artrítica do narrador:

Em Águas de São Pedro Ela e eu andamos muito e para passar o tempo vamos entrando em todos os lugares: hotéis, bazares, restaurantes, postos de gasolina, filiais das caixas econômicas federal e estadual e cafés. Num desses últimos chamado Padaria e Bar Delício, encontrei uma gravura que provoca em mim um contínuo interesse: de tamanho médio, representa uma mocinha segurando um peru. Por mim voltaria muitas vezes ao Bar Delício pretextando uma xícara do mau café que servem, um maço de cigarros que não fumo ou uma caixa de fósforos inútil, a fim de contemplar aquela figura juvenil com a sua ave. Não o fiz no começo por causa de Ela, receando aborrecê-la, mas foi ela quem tomou a iniciativa. Estávamos uma tarde espiando vagamente uma das caixas econômicas quando ponderou que ali não tinha muito o que ver e sugeriu que voltássemos ao bar da menina e do peru. Daí por diante adquiriu o hábito de conversar com os freqüentadores do bar, gente velha que sabia muita coisa. (...) Todos simpatizavam com Ela e enquanto lhe falavam, participando distraidamente da conversa eu ficava olhando para a menina do peru." ${ }^{44}$

${ }^{43}$ GOMES, 2007, p. 103-106.

${ }^{44}$ GOMES, 2007, p. 94-95) Eis o modo crítico (em que um cômico negativo está presente) como Ela avaliará depois este hábito adquirido: "Aludiu com uma precisão inédita ao meu artritismo, às minhas curas em Águas onde ela curtia a humilhação de ser a mulher da figura mais cômica que os porteiros já tinham visto na populaçãao sempre renovada da estância. Exemplo? Todo o vilarejo comentava minha paixão por aquela mocinha ridícula abraçada a um peru." 
$\mathrm{Na}$ descrição da cômica noite de núpcias com Ela (em que ocorre o erro capital de o velho narrador, excitado pela "virgindade" da noiva, não conseguir deflorá-la), ela interrompe "o mal ficar" e explica com muito tato e discrição - usando engenhosos e engraçados termos de comparação - o fiasco ocorrido, mas sem por isso deixar de designar com divertida clareza o encaixe dos órgãos na cópula, a grossura do órgão sexual masculino e o estado indisponível (para a penetração) de um órgão sexual feminino por longos anos virgem:

Ela fez três curtas preleções: uma em torno de nós, a outra sobre mim e a terceira a respeito de si própria. A primeira girou em torno do conceito de gabarito, não no sentido tolo em que é atualmente empregado, mas nas acepções técnicas originais de cálculo de proporções, medida padrão a que se devem conformar certas coisas, vão entre os trilhos de uma via férrea ou de um túnel e o instrumento que serve para verificar essas medidas. A explanação inicial serviu de introdução às duas outras. Na que me tocava de perto, o tema mais abordado foi o do calibre, que estava longe de imaginar tão desenvolvido nos cursos de educação pré-nupcial. Essa parte de sua dissertação, além de muito esclarecedora, teve o dom de afagar o meu amor-próprio um tanto arranhado no momento. (...) Falando a seu respeito durante aquela noite inesquecível, Ela escolheu os termos de comparação no interessante terreno da encadernação. Como se sabe, mas eu não sabia, as célebres e belas

(GOMES, 2007, p. 101). Roberto Schwarz, ao introduzir o já citado "desacordo total" "entre a limitação das personagens e a inteligência de sua escrita", parece estar de algum modo encampando o juízo negativo de Ela: "A prosa é de mestre, mas quem a formula são personagens escolhidamente patetas (...). O senhor que redige a última história passa o melhor de suas tardes olhando para os ladrilhos de um bar em que está pintada uma menina que segura um peru." (SCHWARZ, 2007, p. 128). Esta inverossímil disparidade pode, no entanto, apesar da "excessiva proximidade da piada", conter uma inesperada poesia: "A clarividência que não capitula diante da estupidez mas tampouco lhe desarma os dispositivos representa, em si mesma, um sentimento de vida. Com deliberada isenção, o espírito plana sobre o desenrolar de sua existência privada, onde não falta o primarismo. Há nisto uma superioridade sem presunção de redentora, uma aceitação do que é da contingência, que são façanhas humanas e literárias." (Ibidem). Esta última passagem de Roberto Schwarz nos lembra a definição por Modesto Carone (em seu já citado ensaio sobre o livro de Paulo Emílio) do "uso adstringente do cômico": "Podemos concebê-lo, nas trilhas de Adorno, como a reivindicação de relevância levantada pelo vão-e-fútil em nome de sua mera existência." (CARONE, 2007, p. 151). 
reliures francesas em pele de javali, feitas no século XVIII até aproximadamente a Revolução (...) entram num processo de secura e engruvinhamento que impossibilita não só a leitura do volume mas até o simples manuseio dos amadores. É como se entrassem num profundo recolhimento, se auto-reservando riquezas de que não usufruem devido à impossibilidade de lerem a si próprios e ao mesmo tempo negando aos curiosos potenciais as alegrias secretas que poderiam propiciar. ${ }^{45}$

Mais tarde, em sua pouco pudica confissão, Ela dará detalhes sobre o acontecido na cama naquela noite que não são propriamente lisonjeiros (do ponto de vista erótico) para o narrador. Em referência aos dois pontos talvez excessivos dados pelo doutor Bulhōes para reconstituir sua virgindade, Ela diz: "Depois que lhe contei sua preferência pela escuridão total e pelo enlace clássico, se convenceu que um ponto teria sido mais do que suficiente, ou quem sabe, nenhum.”46 Um pouco depois, ao falar para Polydoro do também cômico e "heróico" re-desvirginamento pelo doutor Bulhôes, Ela conclui assim: "Estou convencida de que você também teria sido capaz se não fosse tão emotivo, se tivesse mais confiança em si próprio. A idade não foi problema e seu instrumental, incomparavelmente mais fino que o de Culhôes, era uma vantagem, pelo menos naquela circunstância." ${ }^{47}$ Mas é em sua primeira referência à noite de núpcias ("para mim um pesadelo") que Ela, em sua confissão viravoltante, alude de modo mais jocoso e desmerecedor ao órgão sexual do narrador: "Como controlei os nervos para evitar a explosão de impaciência que comprometeria tudo! Você não calcula meu esforço de imaginação para a longa conversa sobre gabarito e calibre pois na realidade, perto de Culhões, você era pinto." ${ }^{48}$

No entanto - em sua primeira descrição dessa noite e já também em uma esfera cômico-obscena - o narrador matreiramente sugere, por meio de uma alusão indireta que joga com um segundo sentido (nem sempre perceptível a uma primeira leitura), ao menos a continuidade da sua ereção, que é obviamente condição sine qua non para as tentativas de consumação

\footnotetext{
${ }^{45}$ GOMES, 2007, p. 88-89.

${ }^{46}$ GOMES, 2007, p. 108.

${ }^{47}$ GOMES, 2007, p. 109.

${ }^{48}$ GOMES, 2007, p. 107.
} 
do ato sexual: "Cheguei a culpar pelo não acontecido o meu sentimento falacioso de mocidade que não tomara a precaução de conferir com a realidade, de forma repetida e a curtos intervalos. Contudo, isso era desmentido pela rigidez não só do meu caráter mas do conjunto da minha personalidade física e espiritual.” ${ }^{9}$

Após este atento recorte e exposição dos elementos "pornochanchádicos" apropriados por Paulo Emílio em "P III: duas vazes Ela” (colagem textual comentada, donde esperamos - caso bem efetivada - a própria demonstração do objeto proposto), caberia, no entanto, à guisa de breve conclusão, nos interrogarmos sobre a qualidade mesma pornográfica destes elementos que compõem uma trama cujo desfecho trágico, como vimos, resistiria certamente a uma tal qualificação. Ora, se estes elementos de "P III: duas vazes Ela" de fato remetem tirânica e monomaniacamente à coisa sexual (aqui as relações sexuais de Ela, em suas duas modalidades, com seus três parceiros), como se tudo (ou quase tudo) apontasse para a situação erótica, confirmando assim uma possível definição do que é pornográfico, ${ }^{50}$ nem por isso deixam estes elementos, pelo tragicômico e irônico como são agenciados, de convocar a vida inteira das personagens (envolvidas nesta trama) no exato ponto onde elas se abrem para a perda e uma ilusória identidade pessoal ameaça se romper. Assim como no caso de uma certa tradição literária libertina contemporânea (poderíamos citar, por exemplo, Madame Edwarda e Histoire de l'ail de Georges Bataille ou Le con d'Irène e Les Aventures de Jean-Foutre la Bite de Louis Aragon) - de que, porém, se distingue de modo nítido por sua maneira não diretamente violenta e explícita - também para "P III: duas vezes Ela” valeria o dito lapidar de Paul Goodman citado por Susan Sontag: "A questão não é saber se se trata de pornografia, mas a qualidade da pornografia."

${ }^{49}$ GOMES, 2007, p. 88. Se quiséssemos localizar melhor nessa última frase as palavras que aludem ao citado fenômeno, italicizaríamos rigidez e fisica.

${ }^{50}$ Ver Susan Sontag: “Os livros denominados pornográficos em geral são aqueles cuja preocupação primária, exclusiva e tirânica é com a descrição de 'intenções’ e ‘atividades' sexuais. (...) Não existem sentimentos gratuitos ou não-funcionais, não há devaneios, especulativos ou imagísticos, que sejam irrelevantes ao assunto em questão. (...) Aplica-se o critério de relevância mais estrito possível: tudo deve apontar para a situação erótica.” (SONTAG, 1987, p. 69-70.

${ }^{51}$ SONTAG, 1987, p. 76. 
É certo que diferentemente da pornochanchada - que promete mostrar o que ela pudica e timidamente escamoteia - o conto "P III: duas vezes Ela" dá nomes suficientemente explícitos à coisa sexual (que, por outro lado, ele não exatamente promete em seu título), sem, todavia, jamais chegar a uma atmosfera pornográfica "pestilencial" como a das virulentas transgressões descritas, por exemplo, em A pocilga de Pasolini ou em História do olho de Bataille, situando-se antes no gênero mais leve da comédia erótica de costumes (aproximando-se pois aí em algo da pornochanchada). Distanciando-se tanto da gravidade sacralizante de Histoire de l'œeil de Bataille quanto do grotesco alucinatório de Les Aventures de Jean-Foutre la Bite de Aragon, "P III: duas vezes Ela" parece se apropriar crítica e criativamente de elementos tradicionais de um certo veio cômico-erótico popular (não desprezíveis em si e certamente apreciados por um espírito brincalhão e anticonvencional como o de Paulo Emílio) presentes - segundo (passagem já citada de) Nuno César Abreu - "nos esquetes dos teatros de revista, dos espetáculos mambembes, dos circos e, mesmo, do rádio" e encontráveis na pornochanchada: "situações com peripécias amorosas, piadas cheias de malícia e gags atualizadas da tradição circense." ${ }^{2}$ Se tivéssemos o cuidado prévio de lembrar (além do enquadramento trágico da narrativa) do sofisticado virtuosismo lingüístico dos jogos de palavra obscenos de Paulo Emílio, assim como de sua inteligência crítica abarcante e multidisciplinar, poderíamos paradoxalmente descrever "P III: duas vezes Ela" segundo o modelo genérico (que incluiria também sua galeria de tipos) da pornochanchada tal como definido por Nuno César Abreu: "Uma dramaturgia que oferece como entretenimento os jogos maliciosos da sedução, da conquista e da performance, filtrados por um tipo de humor construído pela ambigüidade e pelo duplo sentido." 53 Ou seja (o que hoje já não surpreenderia em nada o contingente cada vez maior de leitores de Bakhtin): filtrando-o com a graça de sua apurada inteligência crítico-cômica, Paulo Emílio demonstra em "P III: duas vezes Ela" como é possível fazer uma literatura refinada e muito divertida a partir do repertório "baixo" tradicional do cômico-obsceno popular (onde a excitação sexual maior é a de um riso alegre e maroto).

\footnotetext{
52 ABREU, 2006, p. 144.

${ }^{53}$ ABREU, 2006, p. 144.
} 


\section{Referências Bibliográficas}

ABREU, Nuno César de. A pornochanchada como gênero. In: Boca do lixo: cinema e classes populares. Campinas: Editora da Unicamp, 2006. p. 142-144.

ABREU, Nuno César de. O olhar pornô: a representação do obsceno no cinema e no vídeo. Campinas: Mercado de Letras, 1996.

ABREU, Nuno César de. Boca do lixo: cinema e classes populares. Campinas: Editora da Unicamp, 2006.

BERNADET, Jean-Claude. Pornografia, o sexo dos outros. In: MANTEGA, Guido (Org.). Sexo e poder. São Paulo: Brasiliense, 1979.

CANDIDO, Antonio. A nova narrativa. In: A educação pela noite e outros ensaios. São Paulo: Ática, 1989. p. 199-215.

CARONE, Modesto. A fábula do revés e o revés da fábula. In: GOMES, Paulo Emílio Sales. Três mulheres de três PPPês. São Paulo: Cosac Naify, 2007. p. 150-154.

CHANTRAINE, Pierre. Dictionnaire étymologique de langue grecque. 2ème édition. Paris: Klincksieck, 1983. v. 1-2.

EULÁLIO, Alexandre. Paulo Emílio contista satírico. In: GOMES, Paulo Emílio Sales. Três mulheres de três PPPês. São Paulo: Cosac Naify, 2007. p. 154-157.

GARDNIER, Ruy. A rica fauna da pornochanchada. Disponível em: <http:// www.contracampo.com.br/36/ricafauna.htm>, s. d., p. 1-4.

GOMES, Paulo Emílio Sales. Cinema: trajetória no subdesenvolvimento. In: Cinema: trajetória no subdesenvolvimento. São Paulo: Paz e Terra, 1996. p. 85-111.

GOMES, Paulo Emílio Sales. P I: duas vezes com Helena. In: GOMES, Paulo Emílio Sales. Três mulheres de três PPPês. São Paulo: Cosac Naify, 2007. p. 8-37.

GOMES, Paulo Emílio Sales. P II: Ermengarda com H. In: GOMES, Paulo Emílio Sales. Três mulheres de três PPPês. São Paulo: Cosac Naify, 2007. p. 38-85.

GOMES, Paulo Emílio Sales. P III: duas vezes Ela. In: GOMES, Paulo Emílio Sales. Três mulheres de três PPPês. São Paulo: Cosac Naify, 2007. 86-115.

GOMES, Paulo Emílio Sales. Três mulheres de três PPPês. São Paulo: Cosac Naify, 2007.

GRIMAL, Pierre. Dictionnaire de la mythologie grecque et romaine. Paris: Presses Universitaires de France, 1951.

LIDELL, Henry George; SCOTT, Robert. Greek-English Lexicon. 23th Edition. Oxford: Clarendon Press, 1977. 
MOUTINHO, J. G. Nogueira, Três mulheres do sabonete Araxá. In: GOMES, Paulo Emílio Sales. Três mulheres de três PPPês. São Paulo: Cosac Naify, 2007. p. 120-124.

RAMOS, José Mário Ortiz. O cinema brasileiro contemporâneo: Estado, pornochanchada e redefinições (1970-1974). In: RAMOS, Fernão (Org.). História do cinema brasileiro. São Paulo: Art Editora, 1987. p. 401-418.

ROCHA, Glauber. Entrevista. Movimento, 5 jul. 1976, p. 16.

ROVAI, Pedro Carlos. A chanchada é nossa (depoimento a Jean-Claude Bernadet). Movimento, 26 jan. 1976, p. 19.

SCHWARZ, Roberto. Sobre as três mulheres de três PPPês. In: GOMES, Paulo Emílio Sales. Três mulheres de três PPPês. São Paulo: Cosac Naify, 2007. p. 124-146.

SONTAG, Susan. A imaginação pornográfica. In: A vontade radical. Trad. J. R. Martins Filho. São Paulo: Companhia das Letras, 1987, p. 41-76.

SOUZA, José Inácio de Melo. Paulo Emílio no Paraíso. São Paulo: Record, 2002. TAVARES, Zulmira Ribeiro. O brilho e a graça. In: GOMES, Paulo Emílio Sales. Três mulheres de três PPPês. São Paulo: Cosac Naify, 2007. p. 119-120.

\section{Resumo}

Este artigo visa a uma primeira investigação das relações oblíquas do conto "P III: duas vezes Ela" (e também dos outros dois contos de Três mulheres de três PPPês) de Paulo Emílio Sales Gomes com o gênero cinematográfico brasileiro (dos anos 1970) conhecido como "pornochanchada", assim como, por meio desta investigação, a uma tentativa de esboçar uma descrição da natureza peculiar do cômico erótico-obsceno desta ficção de Paulo Emílio.

\section{Résumé}

Cet article vise à une première investigation des rapports obliques de la nouvelle "P III: duas vezes Ela" (ainsi que des autres deux nouvelles de Três mulheres de três PPPês) de Paulo Emílio Sales Gomes avec le genre cinématographique brésilien (des années 1970) connu comme "pornochanchada", aussi bien que, par le moyen de cette investigation, à un essai d'ébaucher une description de la nature particulière du comique érotique-obscène de cette fiction de Paulo Emílio Sales Gomes. 